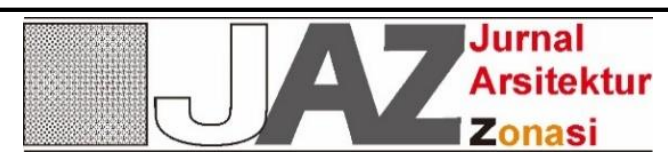

http://ejournal.upi.edu/index.php/jaz - e-mail: jurnal.zonasi@gmail.com dan jurnal_zonasi@upi.edu doi.org/10.17509/jaz.v3i3.28134

\title{
KONDISI KUALITAS UDARA DI DALAM RUANGAN PEMUKIMANAN NON- KUMUH KOTA BANDUNG
}

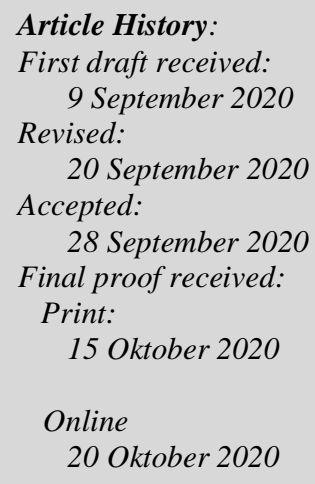

Jurnal Arsitektur ZONASI is indexed and listed in several databases:

SINTA 4 (Arjuna)

GARUDA (Garda Rujukan Digital)

Google Scholar

Dimensions

oneSearch

BASE

Member:
Crossref
RJI
APTARI
FJA (Forum Jurna Arsitektur)
IAI
AJPKM

\author{
R.A Vesitara Kencasari ${ }^{1}$ \\ Usep Surahman ${ }^{2}$ \\ Asep Yudi Permana ${ }^{3}$ \\ Hari Din Nugraha ${ }^{4}$ \\ 1,2,3 Universitas Pendidikan Indonesia, Bandung, Indonesia \\ J1. Dr. Setiabudi No.229, Kota Bandung \\ ${ }^{4}$ Univesitas Subang \\ Jl.R.A Kartini KM.3 Pasirkareumbi, Subang \\ Email: ra.vesitara@upi.edu \\ usep@upi.edu \\ yudi.permana@upi.edu \\ haridinnugraha@unsub.ac.id
}

Abstract: This research was initiated by the factors of poor indoor air quality conditions. So that it can cause Sick Building Syndrome (SBS) or sick building syndrome. The purpose of this research is to measure the picture of air quality conditions in non-slum rooms. The sample in this study was Pasteur Village RW6, Sukajadi District which was selected based on criteria, namely including non-slum areas, as well as high community participation. The research method used was cross-sectional. The results showed an overview of indoor air quality in non-slum dwellings, humidity was above the required standard, thus triggering fungal growth rates that exceeded normal limits. The temperature parameter is in the required category, but based on the findings, some people are uncomfortable with the room temperature in the house. The Formadehilda and VOC parameters are within normal limits, this is indicated because most people do not use chemical products, rarely smoke in the house, and rarely start motorized vehicles in the house.

Keywords: Indoor Air Quality, Sick Building Sindrome (SBS)

Abstrak: Penelitian ini diawali oleh faktor kondisi kualitas udara di dalam ruangan yang buruk. Sehingga dapat menyebabkan terjadinya Sick Building Syndrome (SBS) atau sindrom bangunan sakit. Tujuan peneltian ini adalah untuk mengukur gambaran kondisi kualitas udara di dalam ruangan non kumuh. Sampel pada penelitian ini adalah Kelurahan Pasteur RW6, Kecamatan Sukajadi yang dipilih berdasarkan kriteria yaitu termasuk kawasan non kumuh, serta partisipasi masyarakat yang tinggi. Metode Penelitian yang digunakan adalah cross-sectional. Hasil penelitian menunjukkan gambaran kualitas udara di dalam ruangan pada rumah tinggal non kumuh, kelembaban berada di atas standar yang dipersyaratkan, sehingga memicu tingkat pertumbuhan jamur yang melampaui batas normal. Parameter suhu berada dalam kategori yang dipersyaratkan, namun berdasarkan hasil temuan sebagian masyarakat kurang nyaman dengan suhu ruang pada rumah tinggal. Parameter Formadehilda dan VOC berada pada batas normal, hal tersebut diindikasikan karena sebagian besar masyarakat tidak menggunakan produk-produk kimia, jarang melakukan aktivitas merokok di dalam rumah, serta jarang menghidupkan mesin kendaraan bermotor di dalam rumah.

Kata Kunci: kualitas udara di dalam ruangan, Sick Building Sindrome (SBS) 


\section{Pendahuluan}

Udara sebagai salah satu komponen kehidupan merupakan kebutuhan yang paling utama dalam kelangsungan hidup manusia. Untuk memenuhi hal tersebut maka diperlukan pemeliharan untuk mempertahankan dan meningkatkan mutu (kualitas) udara agar dapat memberikan kontribusi bagi mahluk hidup dalam hal kesehatan (Wulandari, 2014). Udara terdiri dari udara di luar ruangan (outdoor air) dan udara di dalam ruangan (indoor air). Kualitas udara di dalam ruangan merupakan pencerminan dari kondisi parameter udara yang ada di dalam ruangan tersebut. Kualitas udara di dalam ruangan juga dapat diartikan sebagai kondisi udara di dalam ruangan yang mengacu pada kenyamanan dan kesehatan penghuninya (Yau, Chew, \& Saifullah, 2012). Kualitas udara di dalam ruangan sangat mempengaruhi kesehatan manusia, hal ini dapat terjadi karena frekuensi manusia menghabiskan waktu $90 \%$ paling banyak di dalam ruangan dibandingkan di luar ruangan (Lu et al., 2016; Norhidayah et al, 2013).

Kualitas udara di dalam ruangan yang buruk dapat menyebabkan terjadinya Sick Building Syndrome (SBS) atau sindrom bangunan sakit (Sun et. al., 2015). Istilah SBS digunakan untuk menggambarkan masalah kesehatan yang disebabkan oleh kualitas udara di dalam ruangan (Bornehag et al., 2005). Gejala SBS tersebut dapat terjadi secara langsung yaitu: iritasi mata, iritasi hidung dan tenggorokan, sakit kepala, mual, flu, pneumonia, dan penyakit virus lainnya. Selain itu secara tidak langsung dampaknya terjadi setelah beberapa tahun kemudian yaitu: penyakit paru-paru, jantung, kanker, bahkan kematian (EPA, 2008; Roser \& Ritchie, 2019).

Laporan World Health Organization (WHO) pada tahun 2016 terdapat 3,8 juta orang meninggal dikarenakan buruknya kualitas udara di dalam ruangan. Jumlah kematian tersebut paling tinggi terdapat di wilayah Asia Tenggara sebesar 1,5 juta kematian sedangkan wilayah Pasifik Barat sebesar 1,2 juta, Afrika 739.000, Mediterania Timur 212.000, Amerika 82.000, dan Eropa 52.000 kematian (WHO, 2018). Indonesia sebagai salah satu Negara Asia Tenggara memiliki angka kematian sebesar 36,5\% akibat kualitas udara di dalam ruangan yang buruk (Global Health Data, 2017). Angka kematian tersebut di dominasi dengan penyakit ISPA (Infeksi Saluran Pernafasan Atas) atau yang lebih dikenal dengan pneumonia (Fahimah et al., 2014). Penyakit pneumonia tersebut pada umumnya menyerang anak-anak bawah lima tahun (balita). Hal tersebut sejalan dengan penelitian Padmonobo (2013) yang menunjukkan bahwa balita yang terjangkit penyakit pneumonia memiliki kecederungan lebih banyak tinggal di rumah dengan kondisi kualitas udara yang buruk.

Penelitian membuktikan bahwa kondisi kualitas udara yang baik di dalam ruangan memiliki presentase kelembaban sekitar 40-60\%. Apabila presentase kelembaban lebih tinggi dari standar tersebut maka akan memicu pertumbuhan jamur yang bersifat allergen (Citraswari, 2015). Kemudian, suhu yang terlalu tinggi ataupun rendah di dalam ruangan mengakibatkan kondisi yang tidak nyaman dan dapat mempengaruhi kesehatan. Selain dengan memperhatikan standar baku kualitas udara di dalam ruangan, hasil penelitian lain juga menyatakan bahwa kualitas udara di dalam ruangan yang baik dapat dicapai dan dipertahankan dengan memperhatikan sistem ventilasi ruangan, desain, bentuk ruangan, manajemen polutan, dan kesadaran penghuni rumah (Fitria, 2008). Maka berdasarkan hal tersebut penting untuk menyediakan lingkungan yang aman, sehat, dan produktif dalam menjaga kualitas udara di dalam ruangan.

Kenyataanya, terdapat masalah mengenai kondisi fisik bangunan seperti masalah ventilasi udara pada rumah tinggal (Kelly \& Fussell, 2019; Takaoka et al., 2016). Kajian lain juga menunjukkan hal serupa mengenai kualitas udara di dalam ruangan memiliki beragam faktor, diantaranya ventilasi udara yang kurang baik, adanya sumber kontaminan dari luar ruangan, mikroba, bahan material bangunan, kurangnya tingkat kesadaran manusia, dan aktifitas manusia di dalam ruangan (Bornehag et al., 2005; Brown et al., 2015; Escobedo et al., 2014; Lei et al., 2017). Hal ini diperkuat juga dengan studi pendahuluan yang dilakukan di unit rumah tinggal yang membuktikan bahwa banyak unit rumah yang masih belum memenuhi standar kualitas udara yang baik di dalam ruangan.

Kualitas udara di dalam ruangan sebenarnya bisa di ukur dengan parameter yang dipengaruhi oleh (1) kualitas fisik: partikulat, suhu udara, pencahayaan, kelembaban, serta pengaturan dan pertukaran udara; (2) kualitas kimia: sulfur dioksida (SO2), Nitrogen dioksida (NO2), Karbon monoksida (CO), Karbondioksida $(\mathrm{CO} 2)$, Timbal $(\mathrm{Pb})$, asap rokok (Environmental Tobacco Smokel ETS), asbes, Formaldehida (HCHO), Volatile Organic Compound (VOC); (3) kualitas biologi: bakteri dan jamur (MENKES, 2011).

Atas dasar rasionalisasi tersebut, perlunya adanya penelitian untuk mengukur kondisi kualitas udara di dalam ruangan. Hasil dari pengukuran tersebut dapat dijadikan bahan rekomendasi mengenai treatment yang tepat untuk meningkatkan kualitas udara pada rumah tinggal. Penelitian ini memfokuskan mengukur kondisi 
kualitas udara di dalam ruangan yang ditinjau dari indikator pengukuran dalam penelitian ini terdiri dari (1) kualitas fisik: suhu dan kelembaban; (2) kualitas kimia: VOC dan Formaldehida; (3) kualitas biologi: jamur.

\section{Metode Penelitian}

Metode Penelitian yang digunakan adalah cross-sectional. Cross-sectional dipilih karena untuk mengukur kualitas udara yang ditinjau dari suhu, kelembaban, VOC, Formadehilda, dan jamur di dalam ruangan ruangan. Populasi pada penelitian ini adalah masyarakat Kota Bandung. Sampel yang digunakan menggunakan teknik Purposive Sampling yaitu proses pengambilan sampel dilakukan dengan cara menentukan syarat atau kriteria khusus yang sesuai dengan tujuan penelitian. Kriteria tersebut adalah kawasan non-kumuh, partisipasi masyarakat yang tinggi yaitu Ibu dan Kepala Rumah Tangga, hal ini dipilih karena penghuni rumah tinggal memiliki peran penting dalam proses penyehatan dalam rumah terkait dengan aktivitas dan kebiasaan yang dilakukan selama berada di dalam rumah.

Prosedur Penelitian dalam penelitian terdiri dari enam tahapan, mulai dari identifikasi masalah, studi pendahuluan, pengumpulan data, analisis data, rekomendasi dan penarikan kesimpulan. Agar dapat memudahkan dalam cara memandangan permasalahan hingga proses penyelesaian disajikan Gambar 1 di bawah ini mengenai prosedur penelitian sebagai berikut.

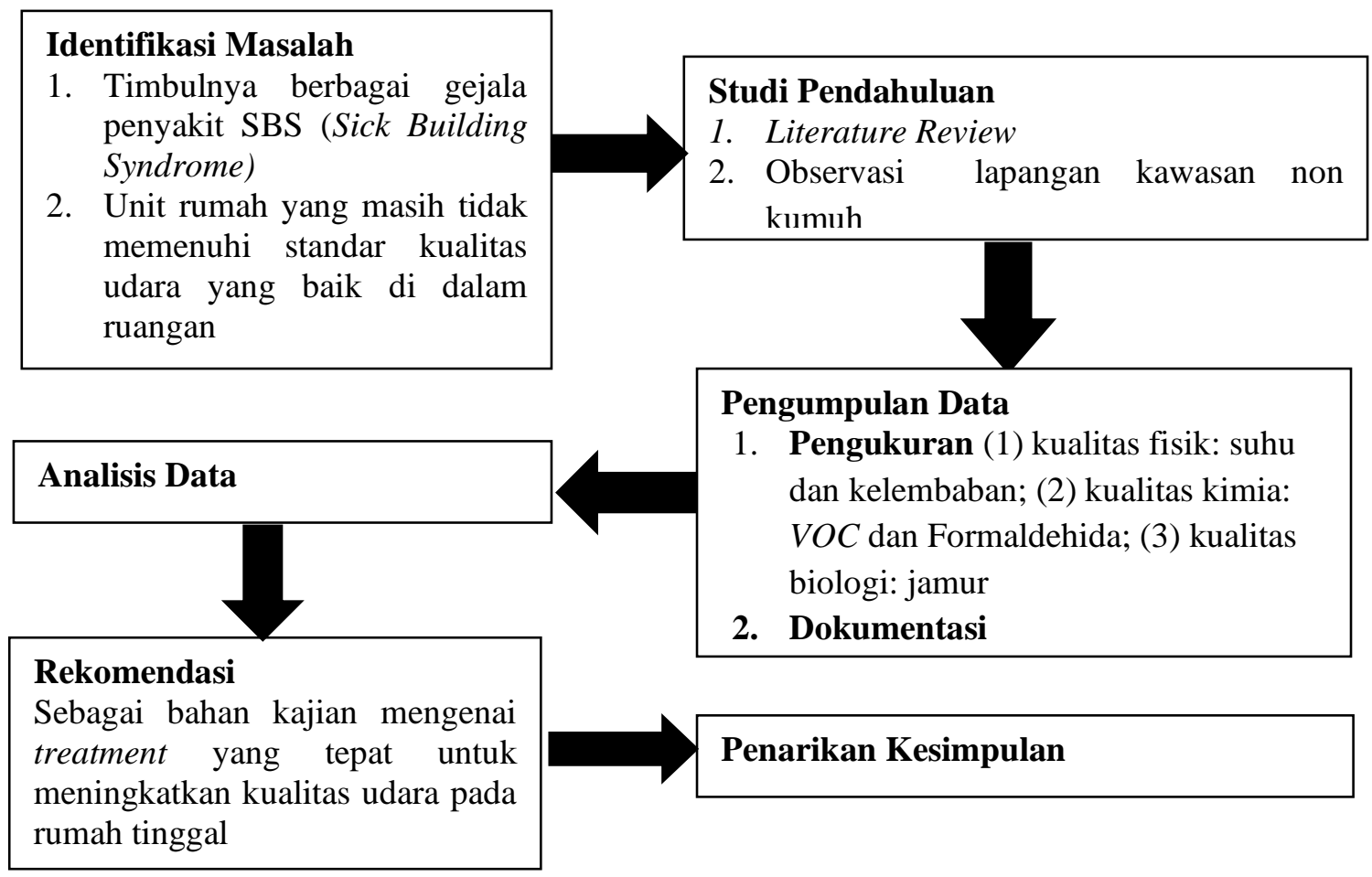

\section{Gambar 1. Prosedur Penelitian}

Pengelompokan kawasan kumuh berdasarkan "SIKAKU" (Basis Data Kawasan Kumuh) Kota Bandung(Permana, 2014)(Permana \& Wijaya, 2017) berdasarkan Badan Pengembangan dan Perencanaan Penelitian Kota Bandung. Berdasarkan peta di atas serta data dari DPKP3 Kota Bandung kawasan yang termasuk dalam kategori kawasan non kumuh adalah Kelurahan Kebun Jeruk, Kelurahan Balong Gede, Kelurahan Situsaeur, Kelurahan Cigondewah Rahayu, Kelurahan Cisaranten Kulon, Kelurahan Cisaranten Endah, Kelurahan Mekar Mulya, Kelurahan Cipadung Kidul, Kelurahan Pasir Jati, Kelurahan Sadang Serang, Kelurahan Pasteur, Kelurahan Gegerkalong, Kelurahan Ciwaruga, Kelurahan Cicadas, dan Kelurahan Sukamaju, Kelurahan Babakan Sari, Kelurahan Sukawarna, Kelurahan Cijerah.

Hasil dari observasi lapangan yang telah dilakukan, Kelurahan Pasteur RW6, Kecamatan Sukajadi dipilih sebagai sampel penelitian. Kelurahan ini dipilih karena merepresentatatifkan daerah yang paling sesuai dengan partisipasi masyarakat tinggi dengan dibuktikan adanya komunitas GEMAS (Gerakan Masyarakat Sehat). Komunitas ini merupakan organisasi yang bergerak dibidang pengelolaan limbah dan perbaikan lingkungan, bahkan gerakan ini memenangkan penghargaan "Kebersihan dan Pengelolaan Limbah" ditingkat Kecamatan Sukajadi(Permana et al., 2018). 

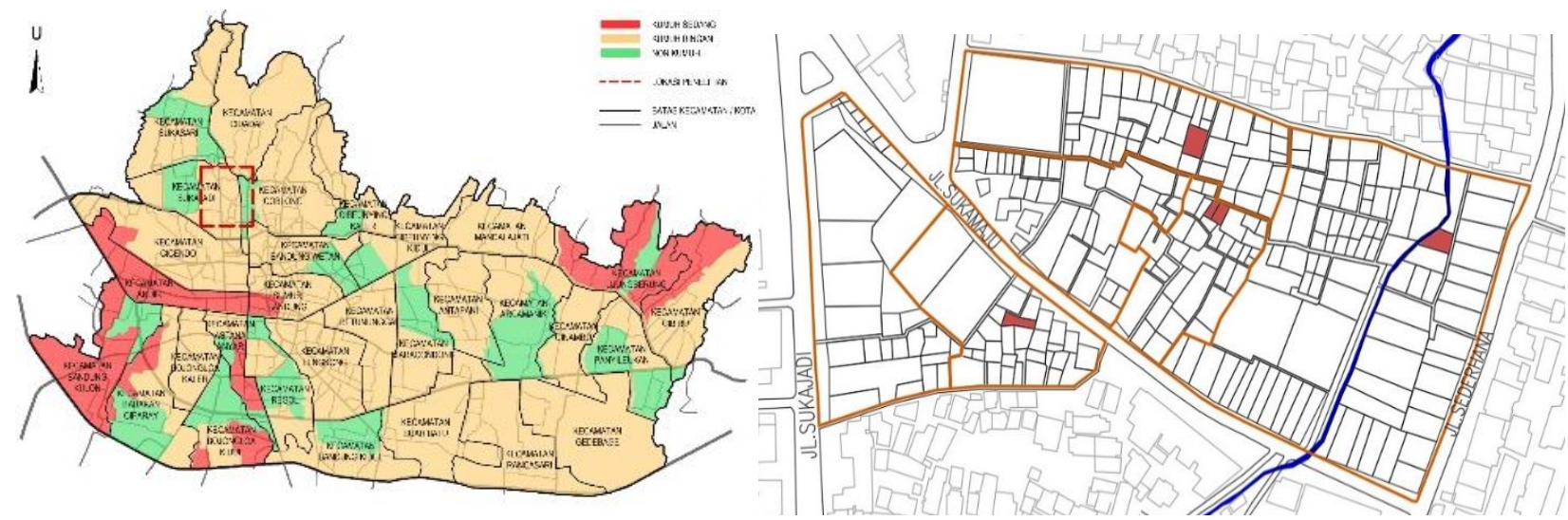

Gambar 2. Kelompok kawasan non-kumuh dan Peta RW 6 Kelurahan Pasteur

\section{Hasil dan Pembahasan}

\subsection{Gambaran kualitas udara di dalam ruangan kawasan non-kumuh}

Pengukuran kualitas udara di dalam ruangan dilakukan pada rumah tinggal masyarakat RW 6 Kelurahan Pasteur Kecamatan Sukajadi, Kota Bandung. Lokasi ini berada di tengah-tengah kawasan perkotaan zona pusat daerah kegiatan (Central Business District) yang merupakan kawasan perbelanjaan, pemukiman, dan perhotelan. Rumah tinggal yang dijadikan sampel pengukuran sebanyak 5 unit rumah tinggal. Sampel dipilih berdasarkan kriteria banyaknya jumlah penghuni rumah tinggal, luas bangunan, kebiasaan merokok, lokasi dengan jalan utama, dan keterbatasan alat ukur. Parameter kualitas udara yang diukur terdiri dari suhu, kelembaban, jamur, Formaldehida, dan VOC.

Teknik pengukuran suhu dan kelembaban menggunakan alat $T \& D T R-52$ yang dipasang pada dinding $10 \mathrm{~cm}$ di atas lantai dengan rentang waktu pengukuran satu minggu. Untuk pertumbuhan jamur menggunakan alat mold sensor yang dipasang di tempat yang tidak terkena sinar matahari langsung, $10 \mathrm{~cm}$ dari dinding atau lantai rumah selama 7 (tujuh) hari. Sedangkan pengukuran Formaldehida menggunakan alat Formaldemeter dan pengukuran VOC menggunakan alat ToxiRae Pro, dengan rentang waktu selama 3 hari, dengan cara dipasang dengan menggunakan tripod dengan jarak minimal $50 \mathrm{~cm}$ dari perabot rumah. Secara spesifik hasil pengukuran terhadap 5 unit rumah tinggal disajikan sebagai berikut.

\subsection{Unit Rumah 1}

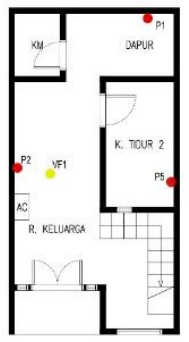

LANTAI 1

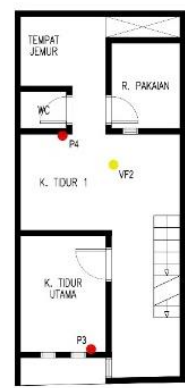

LANTAI 2

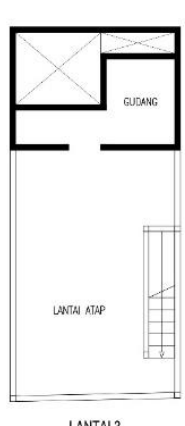

LANTAI 3

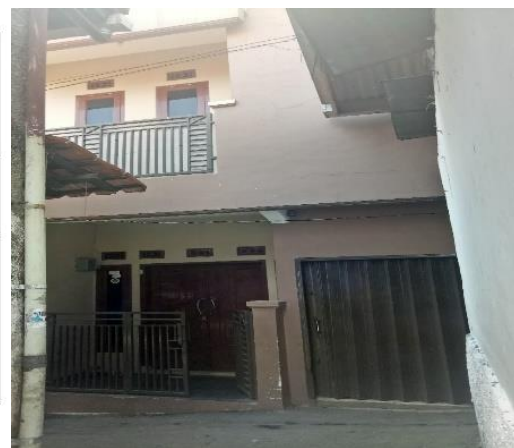

Depan Rumah Unit 1

Sumber: Dokumentasi Penelitian

Gambar 3 di atas merupakan gambar denah dan foto tampak depan pada unit 1. Pengukuran Unit 1 dilaksanakan pada tanggal selama satu minggu. Rumah tinggal unit 1 memiliki ukuran luas bangunan $40 \mathrm{~m}^{2}$ dengan jumlah 3 lantai. Penghuni rumah terdiri dari 2 orang dewasa dan 2 orang anak. Bangunan berusia 5 tahun dan tidak ada perokok aktif di dalam rumah tinggal. 
Tabel 1. Hasil Pengukuran Rumah Unit 1

\begin{tabular}{ll}
\hline Indikator & Hasil \\
\hline Suhu & $25,85^{\circ} \mathrm{C}$ \\
Kelembaban & $74,89 \% \mathrm{RH}$ \\
Jamur & $55,7 \mathrm{CFU} / \mathrm{m}^{3}$ \\
VOC & $0 \mathrm{ppm}$ \\
Formaldehida & $0,028 \mathrm{ppm}$ \\
\hline
\end{tabular}

Berdasarkan hasil pengukuran suhu Tabel 1 pada unit 1 menunjukkan rata-rata kondisi suhu pada unit rumah 1 yaitu sebesar $25,85^{\circ} \mathrm{C}$. Hasil ini dikarenakan pada kamar tidur utama berhadapan langsung dengan tempat jemur, di mana penuntup atapnya menggunakan fiberglass berwarna bening, sehingga sinar matahari yang masuk secara langsung ke dalam ruangan menyebabkan panas dan terperangkap di dalam ruangan yang disebabkan ruangan tersebut tidak memiliki ventilasi yang cukup untuk sirkulasi udara. Berdasarkan data di atas setiap ruangan berada pada rentang yang diijinkan oleh MENKES RI No. 1077 tahun 2011 yaitu 18-30 ${ }^{\circ} \mathrm{C}$, namun berdasarkan hasil di lapangan penghuni merasakan ketidaknyaman dengan kondisi suhu udara pada rumah tingga. Hasil pengukuran kelembaban ruangan rata-rata 74,89 \% RH. Berdasarkan data yang diperoleh dapat di tarik kesimpulan semua ruang Unit 1 memiliki indeks nilai \% RH melebihi batas syarat yang dianjurkan oleh MENKES RI No. 1077 tahun 2011 yaitu 40-60 \%RH. Sedangkan indeks pertumbuhan jamur berada pada nilai rata-rata 55,7 CFU/m. Pertumbuhan jamur pada ruangan dipengaruhi oleh tingginya tingkat kelembaban di dalam ruangan (Tajima et al., 2007; Tsongas \& Rioroan, 2016).

Hasil pengukuran terhadap Formaldehida pada waktu tertentu mempunyai nilai maksimum di atas standar yang diijinkan yaitu $0,1 \mathrm{ppm}$, sedangkan di waktu lainnya memiliki nilai minimal yang jauh di bawah ambang batas yang diijinkan, sehingga nilai rata-rata indeks Formaldehida masih di berada di ambang batas yang diijinkan oleh MENKES RI. Indeks VOC pada rumah tinggal menunjukkan angka 0 ppm, artinya indeks VOC masih berada pada ambang batas yang diijinkan yaitu $\leq 3 \mathrm{ppm}$. Tingkat Formaldehida dan VOC dipengaruhi oleh bahan penutup dinding, plafon, lantai, pintu, serta produk-produk kimia yang dipakai penghuni rumah, seperti pewangi ruangan, minyak wangi, dan kebiasaan merokok di dalam rumah (Adler, 2000). Berdasarkan hasil temuan di lapangan tingkat Formaldehida pada Unit 1 dipengaruhi oleh penggunaan lantai vinyl pada rumah tinggal yang menghasilkan senyawa Formaldehida, sedangkan tingkat VOC menunjukkan indeks 0 ppm dikarenakan pada rumah tinggal tidak menggunakan pewangi ruangan serta tidak ada perokok aktif.

\subsection{Unit Rumah 2}

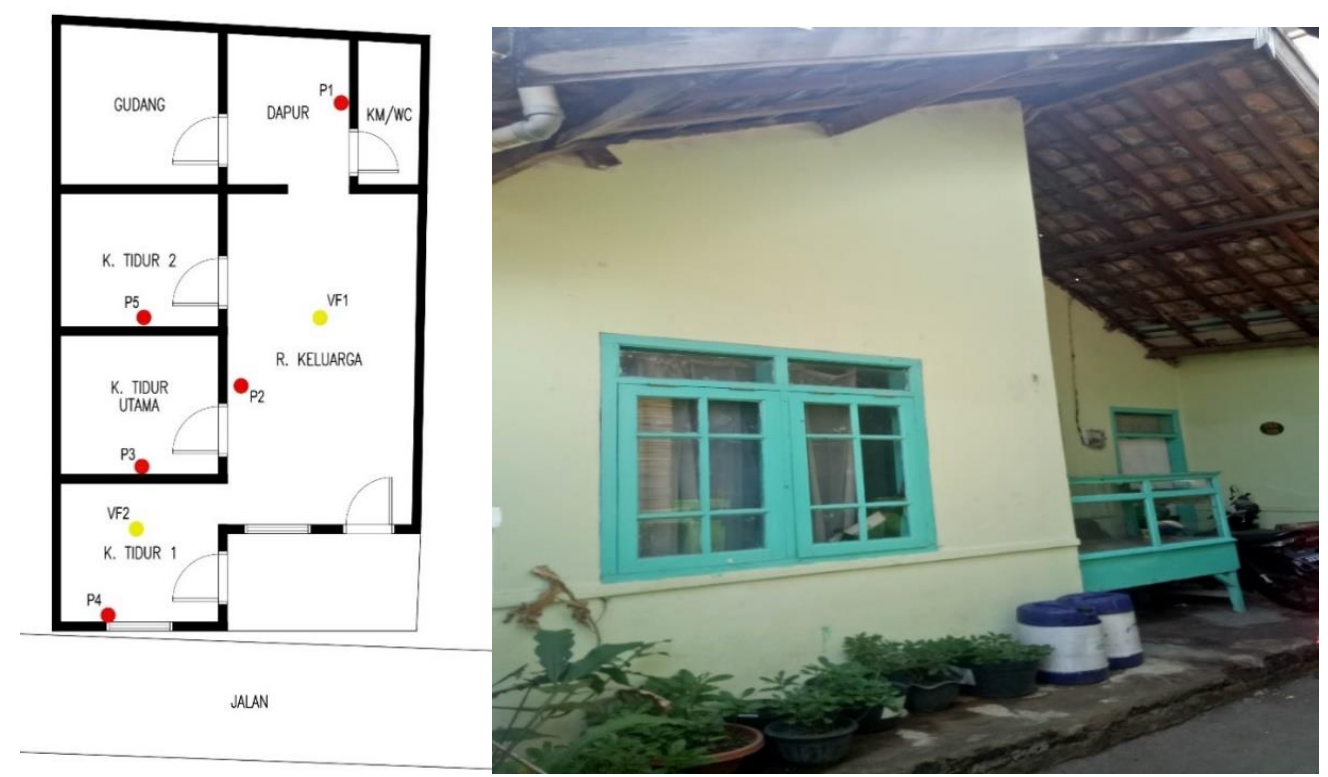

Gambar 4. Denah dan Foto Tampak Depan Rumah Unit 2 Sumber: Dokumentasi Penelitian 
Gambar 4 di bawah ini merupakan denah dan foto tampak depan Unit 2. Rumah tinggal Unit 2 memiliki ukuran luas bangunan $40 \mathrm{~m}^{2}$ dengan jumlah 1 lantai. Penghuni rumah terdiri dari 3 orang dewasa. Bangunan berusia 37 tahun dan tidak ada perokok aktif di dalam rumah tinggal.

Tabel 2. Hasil Pengukuran Rumah Unit 2

\begin{tabular}{ll}
\hline Indikator & Hasil \\
\hline Suhu & $24,73{ }^{\circ} \mathrm{C}$ \\
Kelembaban & $81,1 \% \mathrm{RH}$ \\
Jamur & $47,7 \mathrm{CFU} / \mathrm{m}^{3}$ \\
VOC & $0,01 \mathrm{ppm}$ \\
Formaldehida & $0,02 \mathrm{ppm}$ \\
\hline
\end{tabular}

Berasarkan hasil pengukuran rata-rata suhu ruangan rumah unit 2 yaitu Suhu $24,73^{\circ} \mathrm{C}$ pada rumah tinggal. Hal tersebut dibuktikan dengan hasil temuan dilapangan bahwa yang mengindikasi hal tersebut adalah penggunaan penutup atap asbes pada rumah tinggal. Asbes merupakan penutup atap yang memiliki sifat sebagai penghantar panas yang baik (Utomo \& Cahyono, 2015). Temuan di lapangan juga menunjukkan bahwa penghuni merasa nyaman dengan suhu udara pada rumah tinggal mereka. Berdasarkan hasil yang diperoleh menunjukkan bahwa setiap ruang pada unit 2 berada pada rentang yang diijinkan oleh MENKES RI No. 1077 tahun 2011 yaitu $18-30{ }^{\circ} \mathrm{C}$. Hasil pengukuran kelembaban pada unit 2, diperoleh data pada ruang dapur rata-rata kelembaban berkisar rata-rata $81,1 \% \mathrm{RH}$. Hal ini disebabkan pada ruangan tersebut tidak memiliki ventilasi udara serta terdapat kebocoran atap di dalam ruangan tersebut (Sauni et al., 2015). Berdasarkan data yang diperoleh menunjukkan bahwa setiap ruangan memiliki indeks nilai \%RH melebihi batas syarat yang dianjurkan oleh MENKES RI No. 1077 tahun 2011 yaitu 40-60 \%RH. Sedangkan indeks pertumbuhan jamur Hal ini dibuktikan dengan tingkat kelembaban yang tinggi pada ruangan tersebut yaitu $87,11 \%$ RH dan $82,83 \%$ RH (pada Tabel 4.6), sehingga hal tersebut menyebabkan tingginya pertumbuhan jamur yaitu $47,7 \mathrm{CFU} / \mathrm{m}^{3}$. Dari hasil perolehan data dapat ditarik kesimpulan bahwa ruangan berada diatas ambang batas yaitu melebihi $0 \mathrm{CFU} / \mathrm{m}^{3}$.

Berdasarkan Tabel 2 hasil pengukuran terhadap Formaldehida pada Unit 2 berada pada ambang batas yang diijinkan oleh MENKES RI yaitu 0,1 ppm dan untuk indeks VOC juga menunjukkan angka yang memenuhi standar persyaratan yaitu $\leq 3 \mathrm{ppm}$. Sejalan dengan hasil temuan di lapangan bahwa penghuni rumah tidak menggunakan bahan kimia yang dapat memperburuk kualitas udara di dalam ruangan, yaitu tidak menggunakan pewangi ruangan, jarang menghidupkan mesin kendaraan bermotor di dalam rumah, serta tidak ada perokok aktif.

\subsection{Unit Rumah 3}

Gambar 5 di atas merupakan denah dan foto tampak depan Unit 3. Rumah tinggal Unit 3 memiliki ukuran luas bangunan $22 \mathrm{~m}^{2}$ dengan jumlah 2 lantai. Penghuni rumah terdiri dari 3 orang dewasa. Bangunan berusia 15 tahun dan tidak ada perokok aktif di dalam rumah tinggal.
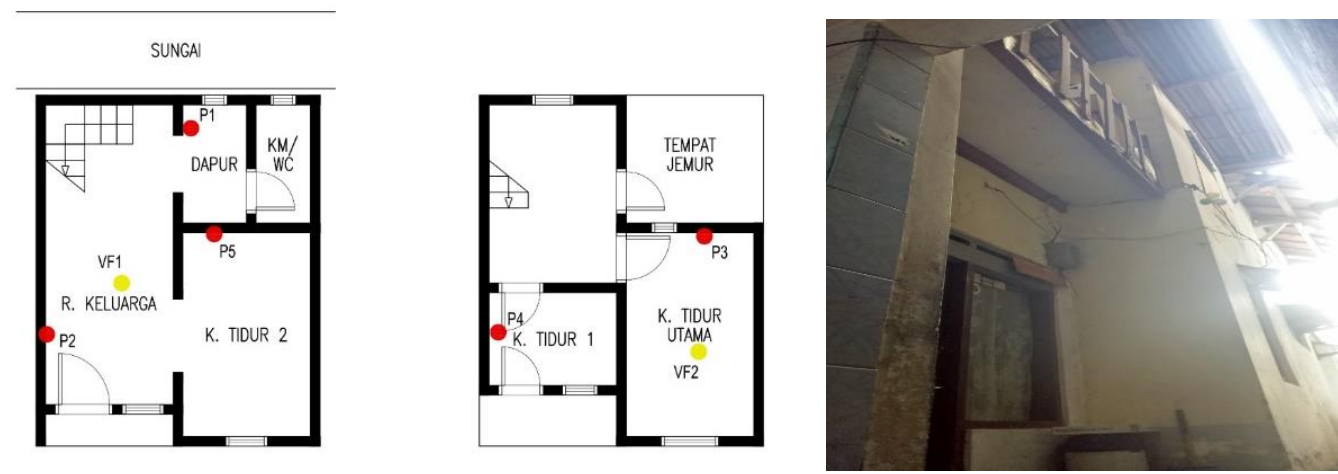

Gambar 5. Denah dan Foto Tampak Depan Rumah Unit 3

Sumber: Dokumentasi Penelitian 
Tabel 3. Hasil Pengukuran Rumah Unit 3

\begin{tabular}{ll}
\hline Indikator & Hasil \\
\hline Suhu & $25,50{ }^{\circ} \mathrm{C}$ \\
Kelembaban & $73,43 \% \mathrm{RH}$ \\
Jamur & $13,64 \mathrm{CFU} / \mathrm{m}^{3}$ \\
VOC & $0,11 \mathrm{ppm}$ \\
Formaldehida & $0,02 \mathrm{ppm}$ \\
\hline
\end{tabular}

Berdasarkan hasil pengukuran suhu Tabel 3 pada Unit 3 suhu rata-rata pada ruang dapur berkisar $25,37{ }^{\circ} \mathrm{C}$. Hasil suhu ruangan disebabkan karena ruangan selalu tertutup rapat meskipun terdapat jendela, serta ruangan berbatasan langsung dengan tempat jemur yang sering dibiarkan terbuka, di mana bahan penutup atap yang digunakan pada tempat jemur adalah seng. Hal tersebut menyebabkan panas yang diterima oleh seng menguap kemudian masuk ke dalam rumah. Sejalan dengan penelitian yang menyatakan bahwa bahan penutup atap berbahan seng merupakan penghantar panas yang baik, sehingga mempengaruhi suhu udara di dalam ruangan (Utomo \& Cahyono, 2015). Secara keseluruhan setiap ruangan pada Unit 3 berada pada rentang yang diijinkan oleh MENKES RI No. 1077 tahun 2011 yaitu 18-30 ${ }^{\circ} \mathrm{C}$. Untuk pengukuran kelembabab diketahui memiliki rata-rata kelembaban sebesar 73,43\%RH. Indeks kelembaban tersebut karena pada ruangan tersebut memiliki ketinggian plafon yang rendah. Sejalan dengan hasil penelitian yang menyatakan bahwa ketinggian plafon pada ruang mempengaruhi suhu dan kelembaban udara di dalam ruangan (Guimarães et al., 2013). Selain itu, tidak adanya cahaya matahari yang masuk ke dalam ruangan dikarenakan jendela selalu dibiarkan tertutup. Berdasarkan hasil pengukuran kelembaban pada Unit 3 secara keseluruhan dapat diartikan bahwa setiap ruangan memiliki indeks nilai $\% \mathrm{RH}$ melebihi batas syarat yang dianjurkan oleh MENKES RI No. 1077 tahun 2011 yaitu 40-60\%RH.

Berdasarkan hasil yang diperoleh nilai indeks rata-rata jamur sebesar 13,64 $\mathrm{CFU} / \mathrm{m}^{3}$. Nilai tersebut memicu pertumbuhan jamur pada ruangan tersebut karena temuan kelemebaban tinggi dan suhu rendah. Dapat disimpulkan bahwa ruangan berada diatas ambang batas yaitu tidak diperbolehkan adanya jamur $(0$ $\mathrm{CFU} / \mathrm{m}^{3}$ ) pada rumah tinggal. Selain itu, hasil pengukuran terhadap Formaldehida pada unit 3 berada pada ambang batas yang diijinkan oleh MENKES RI yaitu indeks rata-rata $0,02<0,1 \mathrm{ppm}$ dan untuk indeks VOC juga menunjukkan angka yang memenuhi standar persyaratan yaitu indeks rata-rata $0 \leq 3 \mathrm{ppm}$. Hal tersebut dibuktikan dengan hasil temuan di lapangan bahwa penghuni rumah tinggal menggunakan produk berbahan kimia seperti pengharum ruangan, pewangi pakaian, minyak wangi, serta kadang-kadang menghidupkan mesin kendaraan bermotor di dalam rumah serta tidak ada perokok aktif.

\subsection{Unit Rumah 4}

Rumah tinggal Unit 4 memiliki ukuran luas bangunan $150 \mathrm{~m}^{2}$ dengan jumlah 1 lantai. Penghuni rumah terdiri dari 2 orang dewasa. Bangunan berusia 37 tahun dan terdapat 1 orang perokok aktif di dalam rumah.
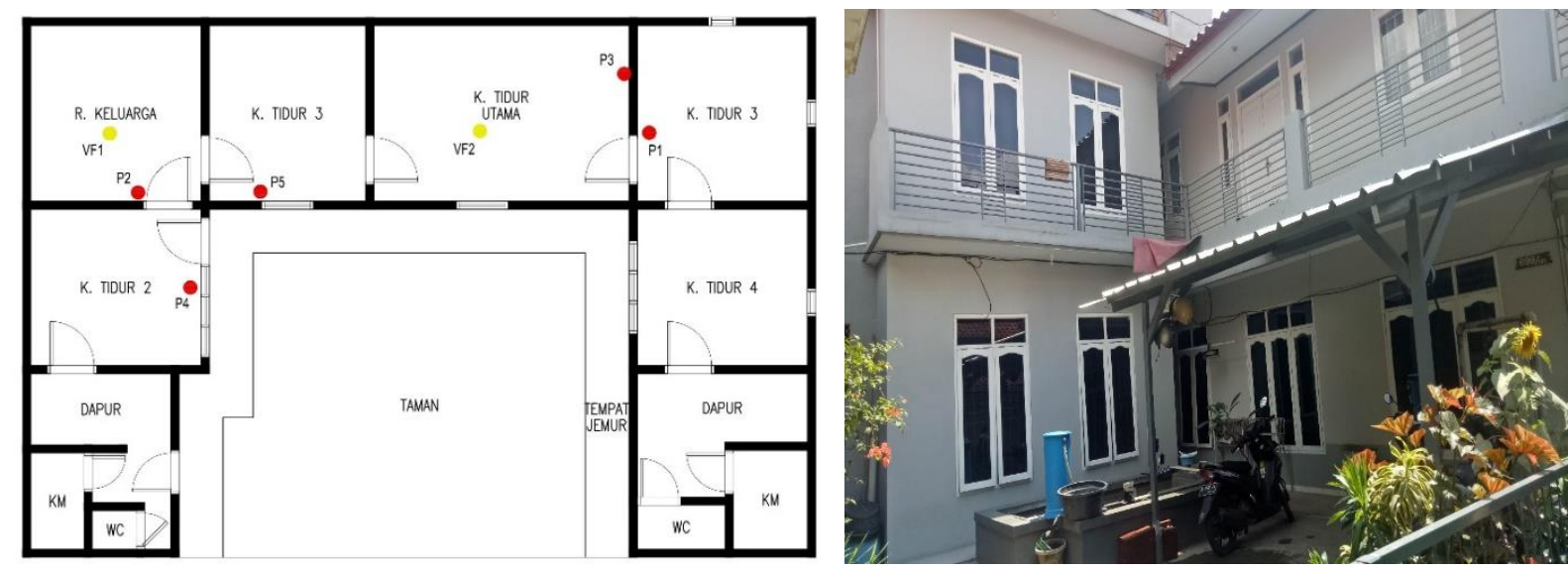

Gambar 6. Denah dan Foto Tampak Depan Rumah Unit 4 Sumber: Dokumentasi Penelitian 


\begin{tabular}{ll}
\multicolumn{2}{c}{ Tabel 4. Hasil Pengukuran Rumah Unit 4 } \\
\hline Indikator & Hasil \\
\hline Suhu & $25,31{ }^{\circ} \mathrm{C}$ \\
Kelembaban & $80,01 \% \mathrm{RH}$ \\
Jamur & $52,6 \mathrm{CFU} / \mathrm{m}^{3}$ \\
VOC & $0 \mathrm{ppm}$ \\
Formaldehida & $0,003 \mathrm{ppm}$ \\
\hline
\end{tabular}

Berdasarkan hasil pengukuran suhu Tabel 4 pada Unit rumah 4, diketahui bahwa suhu rata-rata pada ruangan berkisar antara $25,31^{\circ} \mathrm{C}$. Berdasarkan hasil temuan di lapangan menunjukkan bahwa penghuni rumah tinggal tidak pernah membuka jendela pada saat di dalam rumah, sehingga menyebabkan tidak adanya pertukaran udara dari dalam dan luar ruangan. Sejalan dengan hasil temuan yang menyatakan bahwa kondisi jendela yang tertutup pada rumah tinggal dapat menyebabkan suhu udara di dalam ruangan meningkat (Rijal, et al., 2007), akan tetapi penghuni menyatakan nyaman dengan kondisi suhu udara tersebut. Hasil temuan pada Tabel 4.17 menunjukkan bahwa secara keseluruhan suhu udara pada Unit 4 berada pada rentang yang diijinkan oleh MENKES RI No. 1077 tahun 2011 yaitu 18-30 ${ }^{\circ} \mathrm{C}$. Sedangkan, hasil pengukuran kelembaban rata-rata pada $80,01 \% \mathrm{RH}$, hal tersebut ditandai dengan rendahnya suhu udara pada ruangan tersebut. Berdasarkan Tabel 4 dapat disimpulkan bahwa setiap ruangan memiliki indeks nilai \%RH melebihi batas syarat yang dianjurkan oleh MENKES RI No. 1077 tahun 2011 yaitu 40-60\%RH.

Nilai indeks pertumbuhan jamur rata-rata $52,6 \mathrm{CFU} / \mathrm{m}^{3}$. Pertumbuhan jamur pada setiap ruangan dipengaruhi oleh tingkat kelembaban pada ruangan tersebut. Berdasarkan hasil yang diperoleh maka dapat disimpulkan bahwa disetiap ruangan pada Unit 4 berada diatas ambang batas yaitu tidak diperbolehkan adanya jamur $\left(0 \mathrm{CFU} / \mathrm{m}^{3}\right)$ pada rumah tinggal. Untuk hasil pengukuran terhadap Formaldehida pada unit 4 berada pada ambang batas yang diijinkan oleh MENKES RI yaitu pada rata-rata $0,003<0,1 \mathrm{ppm}$ dan untuk indeks VOC juga menunjukkan angka yang memenuhi standar persyaratan yaitu $0 \leq 3 \mathrm{ppm}$. Hal dibuktikan dengan adanya satu orang perokok aktif pada rumah tinggal, serta penggunaan produk kimia seperti pengharum ruangan dan pewangi pakaian.

\subsection{Unit Rumah 5}

Gambar 7 merupakan denah dan foto tampak depan rumah Unit 5. Rumah tinggal Unit 5 memiliki ukuran luas bangunan $46 \mathrm{~m}^{2}$ dengan jumlah 2 lantai. Penghuni rumah terdiri dari 4 orang dewasa. Bangunan berusia 42 tahun dan terdapat 3 orang perokok aktif.
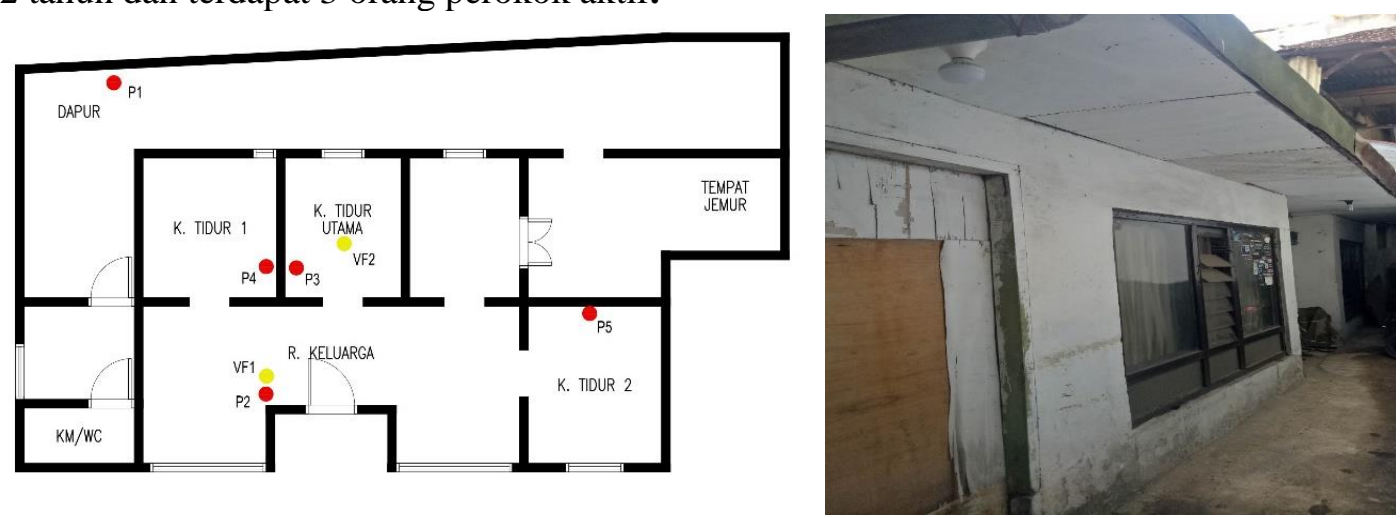

\section{Gambar 7. Denah dan Foto Tampak Depan Rumah Unit 5 Sumber: Dokumentasi Penelitian}

Tabel 5. Hasil Pengukuran Rumah Unit 5

\begin{tabular}{ll}
\hline Indikator & Hasil \\
\hline Suhu & $24,28{ }^{\circ} \mathrm{C}$ \\
Kelembaban & $78,14 \% \mathrm{RH}$ \\
Jamur & $23,54 \mathrm{CFU} / \mathrm{m}^{3}$ \\
VOC & $0 \mathrm{ppm}$ \\
Formaldehida & $0,013 \mathrm{ppm}$ \\
\hline
\end{tabular}


Tabel 5 menunjukkan hasil rata-rata pengukuran pada unit rumah 5 bahwa pada keseluruhan ruangan sebesar $24,28^{\circ} \mathrm{C}$. Berdasarkan hasil temuan di lapangan diketahui bahwa penghuni rumah pada Unit 5 merasa nyaman dengan kondisi suhu pada rumah tinggal, selain itu penghuni rumah tinggal memiliki kebiasaan membuka jendela sehingga terdapat pertukaran udara dari dalam dan luar ruangan. Data yang diperoleh pada tabel 5 dapat disimpulkan bahwa setiap ruangan pada Unit 5 berada pada rentang yang diijinkan oleh MENKES RI No. 1077 tahun 2011 yaitu 18-30 ${ }^{\circ} \mathrm{C}$. Selain itu, hasil pengukuran kelembaban pada Unit 5 yaitu sebesar 78,14 \% RH. Berdasarkan hasil pengukuran didapatkan bahwa ruang keluarga memiliki tingkat kelembaban yang paling tinggi diantara ruangan lainnya, hal ini disebabkan karena terdapat kebocoran atap pada ruang tersebut. Selain itu tingkat kelembaban yang paling rendah berada pada kamar tidur 1 dan 2, dikarenakan pada ruangan ini pintu dan jendela setiap hari dibiarkan terbuka sehingga ada pertukaran udara dari dalam dan luar bangunan. Hasil pengukuran pada Tabel 4.18 dapat disimpulkan bahwa setiap ruangan memiliki indeks nilai \%RH melebihi batas syarat yang dianjurkan oleh MENKES RI No.1077 tahun 2011 yaitu lebih dari 40-60 \%RH. Sedangkan, nilai indeks pertumbuhan jamur sebesar 23,54 CFU/m³. Secara keseluruhan dapat disimpulkan bahwa disetiap ruangan pada Unit 5 berada diatas ambang batas yaitu tidak diperbolehkan adanya jamur $\left(0 \mathrm{CFU} / \mathrm{m}^{3}\right)$ pada rumah tinggal.

Hasil pengukuran terhadap Formaldehida pada Unit 5 berada pada indeks nilai yang melebihi ambang batas yang diijinkan oleh MENKES RI yaitu pada rata-rata $0,013<0,1 \mathrm{ppm}$, hal tersebut diindikasikan karena pada rumah tinggal terdapat perokok aktif yang sering melakukan aktivitas merokok di dalam rumah, sehingga memicu tingkat Formaldehida di dalam ruangan Sementara itu untuk indeks VOC menunjukkan angka yang memenuhi standar persyaratan yaitu $0 \leq 3 \mathrm{ppm}$, hal ini sejalan dengan hasil temuan di lapangan bahwa penghuni rumah tinggal tidak menggunakan bahan-bahan kimia seperti pengharum ruangan, pewangi pakaian, minyak wangi, serta tidak menghidupkan mesin kendaraan bermotor di dalam rumah.

Secara keseluruhan kualitas udara di dalam ruangan dari seluruh unit rumah di RW 6 Pasteur berdasarkan peraturan MENKES RI mengenai standar kualitas udara di dalam ruangan, untuk kategori kualitas fisik: (1) suhu, berada dalam batas normal yaitu berkisar $24-25^{\circ} \mathrm{C}$; (2) kelembaban, berada di atas ambang normal yaitu berkisar antara 73-81 \% RH; kualitas biologi: (3) jamur, juga berada di atas ambang normal yaitu 13-53 CFU/m³ ; dan kualitas kimia: (4) Formaldehida, berada pada batas ambang normal yaitu dengan indeks antara 0,003-0,02 ppm; (5) VOC, juga berada pada batas ambang normal dengan indeks antara 0-0,11 ppm.

\section{Kesimpulan}

Gambaran kondisi kualitas udara di dalam ruangan di Kelurahan Pasteur ditinjau dari parameter kelembaban yaitu berada di atas standar yang dipersyaratkan, sehingga memicu tingkat pertumbuhan jamur yang melampaui batas normal. Parameter suhu pada rumah tinggal berada dalam kategori yang dipersyaratkan, namun berdasarkan hasil temuan sebagian masyarakat kurang nyaman dengan suhu ruang pada rumah tinggal. Parameter Formadehilda dan VOC berada pada batas normal, hal tersebut diindikasikan karena sebagian besar masyarakat tidak menggunakan produk-produk kimia, jarang melakukan aktivitas merokok di dalam rumah, serta jarang menghidupkan mesin kendaraan bermotor di dalam rumah.

\section{Ucapan Terima Kasih}

Terimkasih kepada masyarakat Kelurahan Pasteur RW6 Kecamatan Sukajadi, Kota Bandung yang bersedia membantu dalam proses penelitian.

\section{Referensi}

Adler, L. (2000). Common Indoor Air Pollutants: Sources And Health Impacts. Cooperative Extension Service, 1-3. Retrieved from http://www2.ca.uky.edu/hes/fcs/factshts/hf-lra.161.pdf

Bornehag, C. G., Sundell, J., Hägerhed-Engman, L., \& Sigsgaard, T. (2005). Association between ventilation rates in 390 Swedish homes and allergic symptoms in children. Indoor Air, 15(4), 275-280. https://doi.org/10.1111/j.1600-0668.2005.00372.x

Brown, T., Dassonville, C., Derbez, M., Ramalho, O., Kirchner, S., Crump, D., \& Mandin, C. (2015). Relationships between socioeconomic and lifestyle factors and indoor air quality in French dwellings. 
Environmental Research, 140, 385-396. https://doi.org/10.1016/j.envres.2015.04.012

Citraswari, H., Husein, A., \& Muryoto. (2015). Hubungan Perilaku Penyehatan Udara di dalam Ruang Rumah dan Gangguan Kesehatan Keluarga di Kelurahan Caturtunggal Wilayah Kerja Puskesmas Depok III, Sleman, Yogyakarya. Sanitasi, Jurnal Kesehatan Lingkungan, 6, 157-164.

EPA. (2008). EPA's 2008 Report on the Environment. EPA/600/R-07/045F. 366. https://doi.org/10.1016/B978-0-12-374849-2.00004-6

Escobedo, L. E., Champion, W. M., Li, N., \& Montoya, L. D. (2014). Indoor air quality in Latino homes in

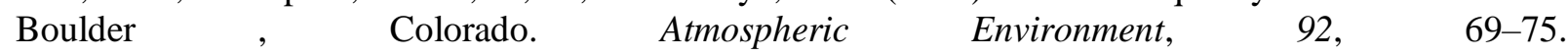
https://doi.org/10.1016/j.atmosenv.2014.03.043

Fahimah, R., Kusumowardani, E., \& Susanna, D. (2014). Home Air Quality And Case Of Pneumonia In Children Under Five Years Old ((In Community Health Center of South Cimahi and Leuwi Gajah, City of Cimahi). Makara Journal of Health Research, 18(1), 25-33. https://doi.org/10.7454/msk.v18i1.3090

Fitria, L. et al. (2008). Kualitas Udara Dalam Ruang Perpustakaan. 12(2), 76-82.

Global Health Data. (2017). GBD Results Tool | GHDx. Institue for Health Metrics and Evaluation. https://doi.org/10.1016/j.entcs.2010.01.004

Guimarães, R. P., Carvalho, M. C. R., \& Santos, F. A. (2013). The influence of ceiling height in thermal comfort of buildings: A case study in belo horizonte, brazil. International Journal for Housing Science and Its Applications, 37(2), 75-86.

Indonesia, M. K. (2011). Peraturan Menteri Kesehatan Republik Indonesia Nomor 1077/MENKES/PER/V/2011 tentang Pedoman Penyehatan Udara dalam Ruang Rumah. https://doi.org/10.1360/zd-2013-43-6-1064

Kelly, F. J., \& Fussell, J. C. (2019). Improving indoor air quality, health and performance within environments where people live, travel, learn and work. Atmospheric Environment, 200(November 2018), 90-109. https://doi.org/10.1016/j.atmosenv.2018.11.058

Lei, Z., Liu, C., Wang, L., \& Li, N. (2017). Effect of Natural Ventilation on Indoor Air Quality and Thermal Comfort in Dormitory during Winter. Building and Environment. https://doi.org/10.1016/j.buildenv.2017.08.051

Lu, C., Deng, Q., Li, Y., Sundell, J., \& Norbäck, D. (2016). Science of the Total Environment Outdoor air pollution, meteorological conditions and indoor factors in dwellings in relation to sick building syndrome ( SBS ) among adults in China. Science of the Total Environment, 560-561, 186-196. https://doi.org/10.1016/j.scitotenv.2016.04.033

Norhidayah, A., Chia-kuang, L., Azhar, M. K., \& Nurulwahida, S. (2013). Indoor Air Quality and Sick Building Syndrome in Three Selected Buildings. Procedia Engineering, 53(2010), 93-98. https://doi.org/10.1016/j.proeng.2013.02.014

Padmonobo, H., Setiani, O., \& Joko, T. (2013). Hubungan Faktor-Faktor Lingkungan Fisik Rumah dengan Kejadian Pneumonia pada Balita di Wilayah Kerja Puskesmas Jatibarang Kabupaten Brebes. Jurnal Kesehatan Lingkungan Indonesia, 11(2), 194-198.

Permana, A. Y. (2014). Fleksibilitas Ruang Perkotaan di Kawasan Balubur-Tamansari Kota Bandung (Issue 0011046901). Universitas Diponegoro Semarang

Permana, A. Y., \& Wijaya, K. (2017). Spatial change transformation of educational areas in Bandung Spatial change transformation of educational areas in Bandung. IOP Conference Series: Earth and Environmental Science, 99, 012029. https://doi.org/10.1088/1755-1315/99/1/012029

Permana, A. Y., Susanti, I., \& Wijaya, K. (2018). The Transformation of Gegerkalong Girang Area, Bandung City: amid Educative and Religious Areas. IOP Conference Series: Earth and Environmental Science, 213(1), 012022. https://doi.org/10.1088/1755-1315/213/1/012022

Rijal, H. B., Tuohy, P., Nicol, F., Humphreys, M. A., \& Clarke, J. (2007). A window opening algorithm and UK office temperature: Field results and thermal simulation. IBPSA 2007 - International Building Performance Simulation Association 2007, 709-716.

Roser, M., \& Ritchie, H. (2019). Indoor Air Pollution - Our World in Data. "Indoor Air Pollution". Published Online at OurWorldInData.Org.

Sauni, R., Jh, V., Uitti, J., Jauhiainen, M., Kreiss, K., \& Sigsgaard, T. (2015). Remediating buildings damaged by dampness and mould for preventing or reducing respiratory tract symptoms, infections and asthma ( Review ). Cochrane Database of Systematic Reviews, (2). https://doi.org/10.1002/14651858.CD007897.pub3.www.cochranelibrary.com

Sun, Y., Wang, P., Zhang, Q., Ma, H., Hou, J., \& Kong, X. (2015). Indoor Air Pollution and Human Perception in Public Buildings in. Procedia Engineering, 121, 552-557. 
Tajima, K., Nonaka, I., Higuchi, K., Takusari, N., Kurihara, M., Takenaka, A., ... Aminov, R. I. (2007). Influence of high temperature and humidity on rumen bacterial diversity in Holstein heifers. Anaerobe, 13(2), 57-64. https://doi.org/10.1016/j.anaerobe.2006.12.001

Takaoka, M., Suzuki, K., \& Norbäck, D. (2016). Sick Building Syndrome among Junior High School Students in Japan in Relation to the Home and School Environment. Global Journal of Health Science, 8(2), 165-177. https://doi.org/10.5539/gjhs.v8n2p165

Tsongas, G. A., \& Rioroan, F. (2016). Minimum conditions for visible mold growth. ASHRAE Journal, 58(9), 32-43.

Utomo, P. U., \& Cahyono, T. (2015). Hubungan Jenis Atap dengan Suhu dan Kelembaban Kamar Tidur di Desa Karangmangu Rw 01 Kecamatan Baturraden Kabupaten Benyumas Tahun 2015. Kesehatan Lingkungan Masyarakat, 35, 112-114.

World Health Organization. (2018). Burden of disease of household air pollution for 2016. 389(10082), 1-4.

Wulandari, E. (2014). Faktor yang Berhubungan dengan Keberadaan Streptococcus di Udara pada Rumah Susum Kelurahan Bandarharjo Kota Semarang Tahun 2013. Unes Journal of Public Health, 3(1), 1-10.

Yau, Y. H., Chew, B. T., \& Saifullah, A. Z. A. (2012). Studies on the indoor air quality of Pharmaceutical Laboratories in Malaysia. International Journal of Sustainable Built Environment, 1(1), 110-124. https://doi.org/10.1016/j.ijsbe.2012.07.005 